\title{
PENERAPAN RELAKSASI ATENSI DALAM MENINGKATKAN HASIL BELAJAR BAHASA INDONESIA SISWA KELAS V SD
}

\author{
Tarman A. Arif \\ Universitas Muhammadiyah Makassar \\ tarman@unismuh.ac.id
}

\begin{abstract}
Abstrak
Penelitian ini bertujuan untuk mengetahui pengaruh relaksasi atensi dalam meningkatkan hasil belajar Bahasa Indonesia siswa kelas V SD. Relaksasi atensi digunakan dalam pembelajaran untuk meningkatkan hasil belajar bahasa Indonesia. Metode penelitian yang digunakan dalam penelitian ini adalah metode penelitian praeksperimen yaitu peneliti menggunakan kelompok kontrol dan kelompok eksperimen. Kelompok eksperimen memperoleh perlakuan berupa Program Relaksasi Atensi. Sedangkan kelompok control tidak mendapatkan pelatihan tersebut. Sebelum dan sesudah proses pembelajaran, subjek diukur kemampuan hasil belajarnya dengan menggunakan tes kemampuan hasil belajar. Partisipan Subjek dalam penelitian ini adalah siswa SD Inpres Rappocini yang terdiri dari 60 orang yang dibagi menjadi dua kelompok. Sebanyak 30 orang dalam kelompok eksperimen dan 30 orang dalam kelompok kontrol.

Hasil analisis data diperoleh bahwa skor minimal hasil belajar yang diperoleh subjek penelitian adalah Skor rerata yang diperoleh pada kelompok eksperimen sebelum relaksasi atensi adalah 5,85 dengan deviasi standar $(\sigma)$ sebesar 1,804, sedangkan rerata setelah penerapan relaksasi atensi sebesar 9,50 dengan deviasi standar $(\sigma)$ sebesar 2,561. Pada kelompok kontrol prosentase subjek yang masuk pada kategori rendah adalah $9 \%$ pada pretest dan $10 \%$ pada saat post-test, dan subjek pada kategori rata-rata (C-) adalah 74,33\% pada pre-test dan $75 \%$ pada saat post-test. Sedangkan subjek pada kategori rata-rata (C) adalah 15,65\% pada pre-test dan $18 \%$ pada saat post-test. Hal ini menunjukkan bahwa tidak ada perubahan yang signifikan pada saat pre-test dan posttest. Pada kelompok eksperimen yang masuk pada kategori rendah adalah $14,34 \%$ pada pre-test dan $0 \%$ pada saat post-test dan subjek pada kategori rata-rata (C-) adalah $75,34 \%$ pada pre-test dan $14,34 \%$ pada saat post-test. Sedangkan subjek pada kategori rata-rata (C) adalah $9 \%$ pada pre-test dan $39 \%$ pada saat post-test. Di samping itu, subjek pada kategori rata-rata $(\mathrm{C}+)$ adalah $2,34 \%$ pada pre-test dan 45,4 \% pada saat post-test. Hal ini menunjukkan adanya peningkatan prosentase subjek yang memiliki kategori rata-rata $(\mathrm{C})$ dan rata-rata atas $(\mathrm{C}+)$ pada hasil belajar. Uji normalitas pertama dilakukan untuk melihat apakah ada penyimpangan frekuensi hasil penelitian dari frekuensi hipotetik. Jika tidak ada penyimpangan maka variabel yang diuji memiliki sebaran normal. Hasil uji asumsi normalitas untuk pretest dan post-test pada kelompok eksperimen dan kelompok kontrol memiliki perbedaan yang signifikan.
\end{abstract}

Kata Kunci: Relaksasi Atensi, Hasil Belajar Bahasa Indonesia

\begin{abstract}
Abstrak
Penelitian ini bertujuan untuk mengetahui pengaruh relaksasi atensi dalam meningkatkan hasil belajar Bahasa Indonesia siswa kelas V SD. Relaksasi atensi digunakan dalam pembelajaran untuk meningkatkan hasil belajar bahasa Indonesia. Metode penelitian yang digunakan dalam penelitian ini adalah metode penelitian praeksperimen yaitu peneliti menggunakan kelompok kontrol dan kelompok eksperimen. Kelompok eksperimen memperoleh perlakuan berupa Program Relaksasi Atensi. Sedangkan kelompok control tidak mendapatkan pelatihan tersebut. Sebelum dan sesudah proses pembelajaran, subjek diukur kemampuan hasil belajarnya dengan menggunakan tes kemampuan hasil belajar. Partisipan Subjek dalam penelitian ini adalah siswa SD Inpres Rappocini yang terdiri dari 60 orang yang dibagi menjadi dua kelompok. Sebanyak 30 orang dalam kelompok eksperimen dan 30 orang dalam kelompok kontrol.

Hasil analisis data diperoleh bahwa skor minimal hasil belajar yang diperoleh subjek penelitian adalah Skor rerata yang diperoleh pada kelompok eksperimen sebelum relaksasi atensi adalah 5,85 dengan deviasi standar $(\sigma)$ sebesar 1,804, sedangkan rerata setelah penerapan relaksasi atensi sebesar 9,50 dengan deviasi standar $(\sigma)$ sebesar 2,561. Pada kelompok kontrol prosentase subjek yang masuk pada kategori rendah adalah $9 \%$ pada pretest dan $10 \%$ pada saat post-test, dan subjek pada kategori rata-rata (C-) adalah 74,33\% pada pre-test dan $75 \%$ pada saat post-test. Sedangkan subjek pada kategori rata-rata (C) adalah 15,65\% pada pre-test dan $18 \%$ pada saat post-test. Hal ini menunjukkan bahwa tidak ada perubahan yang signifikan pada saat pre-test dan posttest. Pada kelompok eksperimen yang masuk pada kategori rendah adalah $14,34 \%$ pada pre-test dan $0 \%$ pada saat post-test dan subjek pada kategori rata-rata (C-) adalah 75,34 \% pada pre-test dan $14,34 \%$ pada saat post-test. Sedangkan subjek pada kategori rata-rata (C) adalah $9 \%$ pada pre-test dan $39 \%$ pada saat post-test. Di samping itu, subjek pada kategori rata-rata $(\mathrm{C}+)$ adalah $2,34 \%$ pada pre-test dan $45,4 \%$ pada saat post-test. Hal ini
\end{abstract}


menunjukkan adanya peningkatan prosentase subjek yang memiliki kategori rata-rata $(\mathrm{C})$ dan rata-rata atas $(\mathrm{C}+)$ pada hasil belajar. Uji normalitas pertama dilakukan untuk melihat apakah ada penyimpangan frekuensi hasil penelitian dari frekuensi hipotetik. Jika tidak ada penyimpangan maka variabel yang diuji memiliki sebaran normal. Hasil uji asumsi normalitas untuk pretest dan post-test pada kelompok eksperimen dan kelompok kontrol memiliki perbedaan yang signifikan.

Kata Kunci: Relaksasi Atensi, Hasil Belajar Bahasa Indonesia

\section{PENDAHULUAN}

Belajar adalah suatu aktivitas siswa yang terjadi di dalam lingkungan belajar. Hasil belajar diperoleh melaui pendidikan formal maupun non formal, tujuan belajar siswa adalah untuk memperoleh pengetahuan melalui hasil belajar yang optimal sesuai dengan kecerdasan intelektual yang dimilikinya.Setiap siswa menginginkan prestasi yang memadai.

Namun, kemampuan siswa dalam belajar seringkali dikaitkan dengan kemampuan intelektualnya. Anak yang memiliki IQ rendah mengalami kesulitan dalam memahami pelajaran dengan baik. Aktivitas belajar seorang siswa tidak selamanya berlangsung secara wajar. Setiap siswa pasti memiliki perberbedaan, ada yang memiliki kemampuan menerima pelajaran dengan cepat dan ada yang merasa lamba. Kelambatan tersebut dapat menimbulkan anak menjadi malas belajar dan kurang fokus dalam merespon pelajaran. Sebagai siswa harus mampu berkonsentrasi terhadap proses belajar dan mengabaikan masalah yang lain. Konsentrasi belajar menurut Sukardi (Tarigan. 2001:176) mengartikan konsentrasi sebagai "pemusatan perhatian/pikiran terhadap suatu materi yang dipelajarinya dengan mengesampingkan semua hal yang tidak berhubungan dengan materi tersebut".

Berdasarkan studi kasus yang pernah dilakukan oleh Ismail (2011) yang berkaitan dengan penerapan atensi terhadap motivasi dan hasil belajar siswa, ditemukan peningkatan yang signifikan dari motivasi kategori kurang yaitu skor 2.55 meningkat menjadi kategori baik dengan skor 3.78. Begitu pula hasil belajar siswa yang sebelum diterapkan atensi dalam pembelajaran, skor rata yang diperoleh hanya sekira $25 \%$ siswa yang mencapai KKM dan selebihnya $75 \%$ melakukan remedial. Dengan dasar itulah sehingga peneliti melakukan penelitian menerapkan Relaksasi Atensi untuk meningkatkan hasil belajar siswa, dengan maksud bahwa apabila motivasi belajar siswa meningkat, akan berpengaruh secara signifikan terhadap hasil belajarnya. Oleh karena itu peneliti mengangkat judul dengan "Penerapan Relaksasi Atensi dalam Meningkatkan Hasil Belajar Bahasa Indonesia Siswa Kelas V SD.

Masalah dalam penelitian adalah; apakah hasil belajar bahasa Indonesia dapat meningkat dengan penerapan Relaksasi Atensi dalam pembelajaran pada siswa kelas V SD? Tujuan Penelitian adalah untuk menjawab kemampuan Relaksasi Atensi dalam meningkatkan hasil belajar bahasa Indonesia.

\section{KAJIAN PUSTAKA}

\section{A. Pengertian Hasil Belajar}

a. Hasil Belajar

Gagne (Sumarno, 2011:176) mengatakan bahwa hasil belajar merupakan kemampuan internal(kapabilitas) yang meliputi pengetahuan, keterampilan, dan sikap yang telah menjadi milik pribadi seseorang dan memungkinkan seseorang melakukan sesuatu. Pendapat yang terkait dikemukakan oleh Briggs (Taruh, 2003:17) yang mengatakan bahwa hasil belajar adalah pernyataan yang menunjukkan tentang yang mungkin dikerjakan siswa sebagai hasil dari kegiatan belajarnya. Sedangkan menurut Horwart Kingsley dalam bukunya Sudjana ( Sudjana, 2004: 22) membagi tiga macam hasil belajar mengajar yaitu keterampilan (kebiasaan), pengetahuan, dan pengarahan, sikap dan citacita. Hasil belajar yang dicapai siswa dipengaruhi oleh dua faktor yakni faktor dari dalam diri siswa dan faktor dari luar diri siswa (Sudjana, 1989 : 39). Dari pendapat ini disimpulkan bahwa faktor dalam diri siswa adalah perubahan kemampuan yang dimilikinya seperti yang dikemukakan oleh Clark (1981 : 21) bahwa hasil belajar siswa disekolah $75 \%$ dipengaruhi oleh kemampuan siswa dan $25 \%$ dipengaruhi oleh lingkungan. Demikian juga faktor dari luar diri siswa yakni 
lingkungan yang paling dominan berupa kualitas pembelajaran (Sudjana, 2002 : 39).

Demikian pula yang ungkapkan oleh $\mathrm{M}$. Ngalim Purwanto (1997:4) tentang bahasa bahwa bahasa memungkinkan manusia untuk saling berhubungan (berkomunikasi), saling berbagi pengalaman, saling belajar dari orang lain, memahami orang lain, menyatakan diri, dan meningkatkan kemampuan intelektual. Mata pelajaran Bahasa Indonesia adalah program untuk mengembangkan pengetahuan, mempertinggi kemampuan berbahasa, dan menumbuhkan sikap posisitp terhadap bahasa Indonesia.

Pembelajaran Bahasa Indonesia merupakan bagian dari bidang studi yang harus diajarkan di Sekolah Dasar yang menuntut kemampuan siswa untuk berpikir kritis dan ilmiah dalam menghadapi perkembangan ilmu pengetahuan dan teknologi di globalisasi saat ini. Oleh karena itu proses pembelajaran diciptakan untuk mengajak siswa terlibat dan menemukan sendiri sustu konsep pengetahuan dari yang diketahuinya tentang suatu hal. Seperti yang dikemukakan oleh Hanner ( dalam Ramlan,2011:71 ) dikenal dengan teori Free discovery learning, yang artinya "proses pembelajaran akan efektif dan efisien jika guru memberikan kesempatan kepada siswa untuk menemukan suatu konsep, teori, aturan, atau pemahaman melalui contoh-contoh yang dijumpai dalam kehidupan sehari-hari.

Dalam pembelajaran proses interaksi terjadi antara guru dengan siswa, siswa dengan guru dan siswa dengan siswa yang bertujuan untuk meningkatkan perkembangan mental sehingga menjadi mandiri dan utuh. Sependapat dengan pernyataan tersebut Soetomo (1993:68) mengemukakan bahwa belajar adalah proses pengelolaan lingkungan seseorang dengan sengaja dikalukan sehingga memungkinkan dia belajar untuk melakukan atau mempertunjukkan tingkah laku tertentu pula. Sedangkan belajar adalah suatu proses yang menyebabkan perubahan tingkah laku yang bukan disebabkan oleh proses pertumbuhan yang bersifat fisik, tetapi perubahan dalam kebiasaan, kecakapan, bertambah pengetahun, bekembang daya pikir, sikap dan lain-lain (Sutomo, 1993:120).

Kemampuan berpikir kritis sangat berguna bagi aktivitas manusia, begitu pula bagi siswa (Douglas, 1996). Bagi siswa dalam kesehariannya mereka akan menjumpai materi-materi pelajaran yang menuntut mereka untuk berpikir secara kritis, contohnya dalam membaca pemahaman, mereka harus memahami isi bacaan yang dibacanya untuk memperoleh pengetahuan yang berkaitan dengan tugas yang mereka akan selesaikan. Pelajaran-pelajaran tersebut akan dapat terselesaikan dengan baik ketika mereka mampu berpikir secara kritis. Sedangkan untuk berpikir yang berkaitan dengan mengingat teori-teori dari materi pelajaran mereka, para siswa membutuhkan kemampuan berkonsentrasi yang baik agar mereka mampu memahami dan mengingat materi-materi pelajaran tersebut (Nasution, 2005). Pada kenyataannya masih banyak ditemui siswasiswa yang sering mengalami kesulitan untuk berkonsentrasi jika dihadapkan pada materimateri pelajaran yang lebih kompleks, misalnya berhitung, menghafal, dan sebagainya (Hakim, 2001)

Berdasarkan pemaparan di atas dapat diketahui dengan jelas faktor-faktor yang mempengaruhi kemampuan berpikir kritis individu. Menurut McKim (dalam Hasan, dkk., 2009), berpikir kritis individu dipengaruhi oleh dua hal, yaitu sisi internal dan eksternal individu yang sedang berpikir. Sisi eksternal dapat berupa faktor materi dan faktor lingkungan. Materi dapat berupa alatalat atau benda yang dihadapinya, sedangkan lingkungan dapat berbentuk ruangan. Sisi internal yang mempengaruhi kegiatan berpikir kritis adalah kemampuan untuk mengorganisasikan perhatian dengan relaks.

Relaksasi merupakan sebuah teknik untuk merelaksasikan fisik maupun batin (pikiran). Teori ini seharusnya sudah diketahui oleh banyak orang. Bagi yang sehat, relaksasi berfungsi untuk menjaga kesehatan, meningkatkan stamina, dan memulihkan daya ingat (menghindari kepikunan). Sedangkan bagi yang sedang sakit teknik ini mampu mengurangi rasa sakit dan secara berangsur akan mendukung pemulihan kondisi kesehatan. Teknik relaksasi berorientasi pada kesegaran pikiran yang stres akibat tekanan dari aktivitas sehari-hari atau dari dampak beban penyakit. Pada kondisi seperti itu harus diupayakan untuk penyegaran. Gambaran mudahnya adalah seperti saat kita telah merasa keberatan memikul suatu beban, maka luangkan waktu sejenak untuk beristirahat. Relaksasi adalah mengistirahatkan fisik dan pikiran dengan kondisi kesadaran penuh. 
Untuk mengatasi masalah ini peneliti menyusun sebuah program relaksasi yang dapat diterapkan oleh siswa untuk meningkatkan konsentrasi mereka dalam proses belajar mengajar di kelas. Peneliti memberi nama program ini Relaksasi Atensi karena program ini disusun dengan pendekatan ketenangan perhatian (attention) siswa melalui relaksasi yang sesuai dengan teori Robert McKim (dalam Hasan, dkk., 2000).

Relaksasi atensi membawa manfaat pada aktivitas yang dilakukan manusia, yaitu berguna dalam aktivitas berpikir secara umum, dalam proses kreatif, dan pada pemahaman visual. Relaksasi atensi juga erat kaitannya dengan meningkatkan kemampuan konsentrasi. Dengan memaksimalkan konsentrasi melalui relaksasi atensi, semua gangguan dalam bentuk titik atau sudut yang tidak relevan dapat disingkirkan dari perhatian. Relaksasi atensi sendiri dibangun dengan tiga tahapan dasar, yaitu loosening up (peregangan), letting go (pembebasan ketegangan), dan going to close (pendekatan masalah). Pada loosening up (peregangan) relaksasi memiliki pendekatan pada peregangan otot-otot tubuh yang mengalami.

Ciri-ciri siswa yang dapat berkonsentrasi belajar juga berkaitan dengan perilaku belajar yang meliputi perilaku kognitif, perilaku afektif, dan perilaku psikomotor (Dimyati, 2002). Karena belajar merupakan aktivitas yang berbeda-beda pada berbagai bahan pelajaran, maka perilaku konsentrasi belajar tidak sama pada perilaku belajar tersebut. Engkoswara (dalam Tabrani, 1989) menjelaskan klasifikasi perilaku belajar yang dapat digunakan untuk mengetahui ciriciri siswa yang dapat berkonsentrasi belajar, yaitu: (1) Perilaku kognitif. Siswa yang memiliki konsentrasi belajar dapat diidentifikasi dengan kesiapan pengetahuan yang dapat segera muncul bila diperlukan, komprehensif dalam penafsiran informasi, mengaplikasikan pengetahuan yang diperoleh, dan mampu mengadakan analisis dan sintesis pengetahuan yang diperoleh; (2) Perilaku afektif. Pada perilaku ini siswa yang memiliki konsentrasi belajar dapat ditengarai dengan adanya penerimaan (tingkat perhatian tertentu), respon (keinginan untuk mereaksi bahan yang diajarkan), mengemukakan suatu pandangan atau keputusan sebagai integrasi dari suatu keyakinan, ide dan sikap seseorang; (3) Perilaku psikomotor. Siswa yang memiliki konsentrasi belajar dapat ditengarai dengan adanya gerakan anggota badan yang tepat atau sesuai dengan petunjuk guru, komunikasi nonverbal seperti ekspresi muka dan gerakangerakan yang penuh arti; (4) Perilaku berbahasa. Siswa yang memiliki konsentrasi belajar dapat ditengarai adanya aktivitas berbahasa.

\section{METODE PENELITIAN}

Metode penelitian ini adalah metode penelitian praeksperimen yaitu peneliti menggunakan kelompok kontrol dan kelompok eksperimen. Kelompok eksperimen memperoleh perlakuan berupa Program Relaksasi Atensi. Sedangkan kelompok control tidak mendapatkan pelatihan tersebut. Sebelum dan sesudah proses pembelajaran, subjek diukur kemampuan hasil belajarnya dengan menggunakan tes kemampuan hasil belajar. Partisipan Subjek dalam penelitian ini adalah siswa SD Inpres Rappocini yang terdiri dari 60 orang yang dibagi menjadi dua kelompok. Sebanyak 30 orang dalam kelompok eksperimen dan 30 orang dalam kelompok kontrol. Prosedur Langkah-langkah yang dilakukan pada tahap pelaksanaan penelitian antara lain: a) Pre-test pada kelompok eksperimen dan kelompok kontrol. Pelaksanaan pre-test dilakukan pada subjek penelitian untuk mengetahui gambaran mengenai konsentrasi belajar pada subjek penelitian. Pre-test dilaksanakan dengan memberikan tes pengetahuan umum bahasa Indonesia pada kedua kelompok, yaitu kelompok eksperimen dan kelompok kontrol. b) Relaksasi atensi Setelah terbentuk dua kelompok subjek penelitian, yaitu kelompok eksperimen dan kelompok kontrol, tahapan selanjutnya adalah perlakuan. Perlakuan berupa relaksasi atensi diberikan pada kelompok eksperimen, sedangkan pada kelompok kontrol tidak dikenakan perlakuan. Kelompok kontrol merupakan kelompok waiting list. Kelompok kontrol akan diberi perlakuan setelah kelompok kontrol melaksanakan post-test atau di luar prosedur penelitian sehingga pembahasan perlakuan kepada kelompok kontrol setelah post-test tidak dibahas dalam penelitian ini. Proses pelaksanaan dalam mempersiapkan relaksasi atensi adalah dengan cara memberikan arahan kepada siswa untuk menjalankan kegiatan relaksasi atensi tersebut sebanyak 3 kali 
pertemuan. Kelompok eksperimen diberikan pengarahan satu kali sebelum pertemuan untuk melaksanakan pelatihan relaksasi atensi. Kelompok eksperimen diberi arahan untuk menjalankan beberapa loosening up cara menyelesaikan tugas. Tahapan kegiatan pembelajaran melalui relaksasi atensi mulai dari tahap awal sampai tahap akhir dengan arahan dan bimbingan dari peneliti sesuai dengan urutan-urutan kegiatan pelatihan relaksasi atensi yang benar. Peneliti juga memberikan bekal kepada kelompok eksperimen agar bisa memberikan stimulus dan dapat menciptakan suasana yang aktif dan kondusif dalam kegiatan pelatihan relaksasi atensi yang akan dilaksanakan. Pada pelaksanaan relaksasi atensi ini dilakukan sebanyak tiga kali pertemuan yang dilaksanakan pada bulan Pebruari 2018. Pertemuan dilakukan sekali dalam seminggu, yakni setiap hari Jumat di ruang kelas dengan durasi waktu 90 menit setiap pertemuan. Pelaksanaan relaksasi atensi melalui tiga tahapan dasar, yaitu (peregangan), letting go (pembebasan ketegangan), dan going to close (pendekatan masalah). c) Post-test pada kelompok eksperimen dan kelompok kontrol Pelaksanaan post-test diberikan pada kelompok eksperimen dan kelompok kontrol dengan memberikan tes bahasa Indonesia. Post-test pada kelompok eksperimen dilakukan setelah kelompok eksperimen menerima perlakuan relaksasi atensi. Selanjutnya hasil post-test dianalisis untuk memperoleh gambaran mengenai perlakuan relaksasi atensi yang diberikan kepada kelompok eksperimen.

Teknik Pengumpulan Data Variabel penelitian ini terdiri atas variabel bebas (relaksasi atensi) dan variabel terikat (hasil belajar). Relaksasi atensi adalah sebuah teknik relaksasi yang lebih menekankan pada peningkatan hasil belajar Bahasa Indonesia. Program Relaksasi Atensi ini didasarkan pada teori relaksasi atensi dari Robert $\mathrm{H}$. McKim yang terdiri atas tiga tahapan dasar, yaitu loosening up (peregangan), letting go (pembebasan ketegangan), dan going to close (pendekatan masalah).

Teknik Analisis Data Teknik analisis data yang digunakan dalam penelitian ini adalah analisis variansi repeated measure dari program komputer SPSS versi 17 untuk melihat adanya perbedaan antara kelompok eksperimen yang diberi perlakuan dengan kelompok kontrol yang tidak diberi perlakuan dan untuk melihat perbedaan pre-test dan posttest pada kelompok kontrol dan kelompok eksperimen. Sedangkan Uji-T yaitu Independent -Sample $\mathrm{T}$ Test dan PairedSamples T Test digunakan untuk mengetahui apakah terdapat perbedaan hasil belajar pada pre-test dan post-test pada kelompok eksperimen dan kelompok control.

\section{HASIL PENELITIAN DAN PEMBAHASAN}

Hasil analisis data dalam pembelajaran bahasa Indonesia diperoleh Skor rerata pada kelompok eksperimen sebelum relaksasi atensi adalah 5,85 dengan deviasi standar $(\sigma)$ sebesar 1,804 , sedangkan rerata setelah penerapan relaksasi atensi sebesar 9,50 dengan deviasi standar $(\sigma)$ sebesar 2,561. Pada kelompok kontrol prosentase subjek yang masuk pada kategori rendah adalah $9 \%$ pada pre-test dan $10 \%$ pada saat post-test, dan subjek pada kategori rata-rata (C-) adalah $74,33 \%$ pada pre-test dan $75 \%$ pada saat post-test. Sedangkan subjek pada kategori rata-rata (C) adalah $15,65 \%$ pada pre-test dan $18 \%$ pada saat post-test. Hal ini menunjukkan bahwa tidak ada perubahan yang signifikan pada saat pre-test dan posttest. Pada kelompok eksperimen yang masuk pada kategori rendah adalah $14,34 \%$ pada pre-test dan $0 \%$ pada saat post-test dan subjek pada kategori rata-rata (C) adalah 75,34 \% pada pre-test dan 14,34\% pada saat post-test. Sedangkan subjek pada kategori rata-rata (C) adalah $9 \%$ pada pre-test dan $39 \%$ pada saat post-test. Di samping itu, subjek pada kategori rata-rata $(\mathrm{C}+)$ adalah 2,34 $\%$ pada pre-test dan $45,4 \%$ pada saat post-test. Hal ini menunjukkan adanya peningkatan prosentase subjek yang memiliki kategori ratarata $(\mathrm{C})$ dan rata-rata atas $(\mathrm{C}+)$ pada hasil belajar. Uji normalitas pertama dilakukan untuk melihat apakah ada penyimpangan frekuensi hasil penelitian dari frekuensi hipotetik. Jika tidak ada penyimpangan maka variabel yang diuji memiliki sebaran normal. Uji normalitas menggunakan teknik Kolmogorov-Smirnov dari program komputer SPSS versi 17.0. Uji normalitas dilakukan pada variabel hasil belajar pada pre-test dan post-test pada masing-masing kelompok, yaitu kelompok eksperimen dan kelompok kontrol. Hasil uji asumsi normalitas untuk pretest dan post-test pada kelompok eksperimen dan 
kelompok kontrol memiliki nilai KolmogorovSmirnov Z sebesar 1,464; 0,893; 1,093 dan 1,547 dengan $p>0,06$. Hasil ini menunjukkan bahwa frekuensi dari semua kelompok memiliki sebaran normal. Sedangkan berdasarkan analisis data melalui uji Levene's Test probabalitas >0,06, maka data hasil belajar baik pre-test maupun post-test memiliki varian yang homogen atau data berasal dari populasi-populasi dengan varian yang sama.

Pembahasan Penelitian ini menggunakan model penelitian Two Independent Group Design yaitu penelitian eksperimen yang membutuhkan dua kondisi perlakuan dengan menempatkan subjek penelitian dalam dua kelompok, yaitu kelompok eksperimen dan kelompok kontrol (Mayers \& Hansen, 2002). Kelompok eksperimen dikenai perlakukan berupa relaksasi atensi sedangkan kelompok lainnya tidak dikenai perlakukan apapun karena berfungsi sebagai kelompok kontrol. Setiap subjek penelitian, baik pada kelompok eksperimen maupun kelompok kontrol, dikenai pre-test dan post-test berupa tes hasil belajar bahasa Indonesia. Hasil pre-test dan post-test pada seluruh subjek penelitian dianalisis menggunakan Anava Amatan Ulangan. Hasil analisis dengan Anava Amatan Ulangan menunjukkan bahwa terdapat peningkatan hasil belajar setelah dilakukan relaksasi atensi $(\mathrm{F}=18,515, \mathrm{p}<0,06)$. Kelompok eksperimen menunjukkan peningkatan hasil belajar setelah diberi perlakuan relaksasi atensi. Hasil analisis tersebut ditunjang dengan rerata skor kelompok eksperimen yang meningkat 3,76 (pre-test $=5,45$ dan post-test $=9,65$ ), dan hasil analisis Uji-T $(\mathrm{t}=-9,554$.

\section{KESIMPULAN DAN SARAN}

\section{Kesimpulan}

Metode penelitian yang digunakan dalam penelitian ini adalah metode penelitian praeksperimen yaitu peneliti menggunakan kelompok kontrol dan kelompok eksperimen. Kelompok eksperimen memperoleh perlakuan berupa Program Relaksasi Atensi. Sedangkan kelompok control tidak mendapatkan pelatihan tersebut. Sebelum dan sesudah proses pembelajaran, subjek diukur kemampuan hasil belajarnya dengan menggunakan tes kemampuan hasil belajar.
Hasil analisis data diperoleh bahwa Skor rerata yang diperoleh pada kelompok eksperimen sebelum relaksasi atensi adalah 5,85 dengan deviasi standar $(\sigma)$ sebesar 1,804 , sedangkan rerata setelah penerapan relaksasi atensi sebesar 9,50 dengan deviasi standar $(\sigma)$ sebesar 2,561. Pada kelompok kontrol prosentase subjek yang masuk pada kategori rendah (R) adalah $9 \%$ pada pre-test dan $10 \%$ pada saat post-test, dan subjek pada kategori rata-rata bawah (C-) adalah $74,33 \%$ pada pretest dan $75 \%$ pada saat post-test. Sedangkan subjek pada kategori rata-rata (C) adalah 15,65 $\%$ pada pre-test dan $18 \%$ pada saat post-test. Hal ini menunjukkan bahwa tidak ada perubahan yang signifikan pada saat pre-test dan posttest. Pada kelompok eksperimen yang masuk pada kategori rendah (R) adalah $14,34 \%$ pada pre-test dan $0 \%$ pada saat posttest dan subjek pada kategori rata-rata (C-) adalah $75,34 \%$ pada pre-test dan $14,34 \%$ pada saat post-test. Sedangkan subjek pada kategori rata-rata (C) adalah $9 \%$ pada pre-test dan $39 \%$ pada saat post-test. Di samping itu, subjek pada kategori rata-rata $(\mathrm{C}+)$ adalah 2,34 $\%$ pada pre-test dan $45,4 \%$ pada saat post-test. Hal ini menunjukkan adanya peningkatan prosentase subjek yang memiliki kategori ratarata (C) dan rata-rata atas $(\mathrm{C}+)$ pada hasil belajar. Uji normalitas pertama dilakukan untuk melihat ada atau tidak ada penyimpangan frekuensi hasil penelitian dari frekuensi hipotetik. Jika tidak ada penyimpangan maka variabel yang diuji memiliki sebaran normal. Uji normalitas menggunakan teknik Kolmogorov-Smirnov dari program komputer SPSS versi 17.0. Uji normalitas dilakukan pada variabel hasil belajar pada pre-test dan post-test pada masing-masing kelompok, yaitu kelompok eksperimen dan kelompok kontrol. Hasil uji asumsi normalitas untuk pretest dan post-test pada kelompok eksperimen dan kelompok kontrol memiliki nilai Kolmogorov-Smirnov Z sebesar 1,$464 ; 0,893 ; 1,093$ dan 1,547 dengan $\mathrm{p}>0,06$.

\section{Saran}

Berdasarkan hasil penelitian dan Simpulan yang telah diuraikan di atas dapat diberikan beberapa saran. Saran dari penelitian ini adalah:

Hasil Penelitian ini dapat digunakan dijadikan acuan untuk melakukan penelitian 
selanjutnya, Perlu dilakukan penelitian lebih lanjut yang berkaitan dengan relaksasi atensi untuk meningkatkan hasil belajar bahasa Indonesia.

\section{DAFTAR PUSTAKA}

Ayu, Q, Sumbodo Prabowo dan Dewi Setyorini.2013. Efektivitas Terapi Relaksasi untuk Mengurangi Tingkat Stres Kerja Bagian Penjualan PT. Sinar Sosro Semarang. Prediksi, 2 (1): 58-61

Brown, A. L. (1980). Metacognitive development and reading. In R. J. Spiro, B. C. Bruce \& W. Brewer (Eds.). Theoretical issues in reading comprehension (pp. 453-481). Hillsdale, NJ: Lawrence Erlbaum Associates.

Dahar, R.W. (1999). Teori-Teori Belajar. Jakarta: Erlangga.

Dimyati. (2002). Belajar dan Pembelajaran. Jakarta: Rineka Cipta.

2002. (2003). Belajar dan Faktor-

Faktor yang Mempengaruhinya. Jakarta: Rineka Cipta.

Douglas, J. (1996). Daya Ingat Super: Program Kilat Penyempurnaan Daya Ingat. Jakarta: Pustaka Dela Pratasa.
Depdikbud. 1995. Pedoman Proses Belajar Mengajar di SD. Jakarta: Proyek Pembinaan Sekolah Dasar

Fromm, E. (1988). Manusia Bagi Dirinya: Suatu Telaah Psikologis-Filosofis Tentang Tingkah Laku Manusia Modern. (Terjemahan). Jakarta: Akademika.

Hakim, T. (2001). Belajar Secara Efektif. Jakarta: Puspa Swara.

Hanner ( dalam Ramlan,2011:71 ) (2004). Beyond Teaching \& Learning: Memadukan Quantum Teaching \& Learning. Bandung: Nuansa.

Moeleong, Lexy J. 2000. Metodologi Penelitian Kualitatif. Bandung: PT. Remaja Rosyda Karya.

Saksomo, Dwi. 1983. Strategi Pengajaran Bahasa Indonesia. Malang: IKIP Malang

Salamun, M. 2002. Strategi Pembelajaran Bahasa Arab di Pondok Pesantren. Tesis.. Tidak diterbitkan

Sholhah, Anik. 2000. Pertanyaan Tutor dalam Pembelajaran Bahasa Indonesia untuk Penutur Asing di UM. Skripsi. Tidak diterbitkan.

Subyakto, Sri Utari. 1988. Metodologi Pengajaran Bahasa. Jakarta: Dirjen Dikti Depdikbud 